\title{
"DE SANGUE" E "DE SANTO": O PARENTESCO NO CANDOMBLÉ
}

\author{
Clara Flaksman ${ }^{1}$ \\ ${ }^{1}$ Universidade Federal do Rio de Janeiro (UFRJ), Museu Nacional, Rio de \\ Janeiro, RJ, Brasil
}

\section{Introdução}

Começo advertindo que o objetivo deste artigo é antes apontar uma direção do que mapear um caminho já traçado e, por isso, talvez haja aqui mais perguntas do que algum tipo de resposta. O tema que desejo abordar baseia-se numa reflexão sobre o parentesco no candomblé, mais especificamente sobre os modelos de transmissão dos orixás (e de outras entidades) entre os membros de uma mesma família e as possíveis conexões entre esses modelos e alguns dos princípios daqueles que se convencionou chamar "novos estudos do parentesco". O objetivo deste artigo é, portanto, analisar a questão do "parentesco de santo", entendido como a rede familiar que surge a partir da feitura do noviço em um terreiro de candomblé, e do "parentesco de sangue", a família consanguínea do iniciado, questionando assim a separação entre elas.

Para isso, retomo uma parte dos materiais etnográficos obtidos durante minha pesquisa de campo no terreiro Ilê Iyá Omi Axé Iyamassé (mais conhecido como Gantois), em Salvador, Bahia (Flaksman 2014). Pretendo analisar dois casos que tive a oportunidade de acompanhar a partir de alguns princípios teóricos advindos dos "novos estudos do parentesco" que, na definição de Janet Carsten (2000:3), se caracterizam pelo relativo abandono de formalismos característicos deste tipo de estudo (uso de tabelas, modelos, genealogias extensas) e por uma ênfase na descrição minuciosa das práticas envolvidas no sistema de parentesco, assim como nos discursos sobre elas. São, segundo Marilyn Strathern (2000), baseados em descrições da relacionalidade e de suas consequências. Afastam-se, portanto, das análises "tradicionais", baseadas no dualismo natureza/cultura - ou seja, parentesco biológico e parentesco social - e buscam, ao invés disso, investigar o parentesco em sua dimensão "processual": no modo como é produzido e atualizado a partir tanto de fatos biológicos como de coabitação, comensalidade, compartilhamento de substâncias e nas 
concepções locais de "dado" e "construído" implicadas nestas relações. Com isso, a ideia de relação ganha força em substituição à ideia do parentesco biológico como algo natural, inerente ao ser humano; o parentesco, antes de ser algo predeterminado, pode ser construído (assim como a pessoa). Desta forma, o "sangue" como particularidade etnográfica ganha novas dimensões: de representação da natureza, como no parentesco ocidental, pode ser visto como construção cultural em outros contextos etnográficos específicos.

Há duas décadas atrás, Eduardo Viveiros de Castro retomou a discussão sobre o parentesco, criticando a noção de natureza que informa toda a história da teoria antropológica (Viveiros de Castro 1996). Essa discussão será retomada depois por Sahlins (2011a, 2011b): retomando um grande número de etnografias produzidas em contextos culturais (e teóricos) diversos, Sahlins conclui que o que denominamos parentesco de fato aponta para um tipo de conexão que em toda parte distingue certas relações, e pode ser definida pela ideia de mutualidade do ser (mutuality of being). A questão colocada por Sahlins é pertinente: indica a possibilidade, ou antes o interesse, de seguirmos falando em parentesco no momento em que abrimos mão dos pressupostos fundadores desse campo de estudos, a saber, a ideia de que estamos buscando codificações culturais variadas para o dado natural que a ciência nos permite conhecer, as relações biológicas de descendência.

Sahlins, curiosamente, afirma que o primeiro antropólogo a identificar o caráter relacional da pessoa foi Roger Bastide, referindo-se à "pessoa africana": "[...] o que está em questão é o caráter das relações mais do que a natureza da pessoa" (2011a:13). Entretanto, a "pessoa africana", para Bastide, não é composta somente por suas entidades e pelas relações que estabelece com elas, mas é constituída, principalmente, por suas histórias (Bastide 1958)..$^{1} \mathrm{O}$ argumento de Bastide, segundo o qual a pessoa é composta de suas histórias, aproxima-se da afirmação de que a pessoa é o conjunto de suas entidades, de que trataremos mais adiante (Goldman 1984) - já que se trata, em última instância, de histórias que envolvem essas entidades, histórias que dizem respeito às relações entre elas e os seres humanos. Para abordar essas relações, utilizaremos a noção de enredo, muito usada no candomblé da Bahia, e que apresentarei a seguir.

\section{Enredo}

Em minha pesquisa de campo, chamou a atenção, desde o início, o fato de que se fala o tempo todo que são as relações familiares (ou seja, consanguíneas) que levam alguém a fazer parte do candomblé. Sabemos 
que a entrada para a religião depende da vontade do orixá, mas a questão se complica quando procuramos entender os motivos mais frequentes da existência dessa vontade. Como vimos, em teoria, qualquer um pode ser chamado a fazer parte do corpo de membros de um terreiro, mas, na prática, poucos o são. Quando eu perguntava por que motivo uma determinada pessoa deveria fazer o santo, a resposta sempre tinha a ver com questões familiares. Mãe Carmem, a mãe de santo do Gantois, me disse um dia: "Às vezes a pessoa chega para fazer o santo e a gente pergunta: 'Tem algum parente seu na religião?', e ela diz, 'não'. Mas aí, depois de um tempo, sempre acaba aparecendo alguém". Ter um parente com questões a acertar no plano espiritual, com relações não resolvidas com seus próprios orixás, herdar o orixá de algum antepassado, tudo isso leva alguém a precisar fazer o santo. Os orixás têm famílias próprias e fazem parte de famílias humanas, caracterizando-se de maneira a absorver certos traços dessas famílias e ao mesmo tempo emprestar a elas algumas de suas características.

Essas relações de parentesco se revelam com frequência no jogo de búzios. Conheci uma pessoa que começou a frequentar uma casa de candomblé jovem, "por curiosidade", como ele me descreveu. Depois de algumas visitas, jogou búzios com a mãe de santo. Esta, assim que jogou os búzios, viu que ele era de Ogum, mas um Ogum que retornava à sua família. Ele respondeu que era impossível, que sua família não tinha nenhuma ligação com o candomblé. "Procure saber", lhe disse a mãe de santo. Ele foi então à procura de alguma história familiar que lhe fosse desconhecida, duvidando muito que encontraria algo. Ao conversar com sua avó, porém, ela lhe contou que certo dia ouvira de sua mãe (portanto, da bisavó do consulente) referências ao seu primeiro marido, que teria abandonado a família para ser pai de santo. Ela não sabia mais detalhes, mas a sorte é que a essa altura a velha senhora ainda estava viva, morando numa pequena cidade do Recôncavo Baiano.

Ele foi então procurar a bisavó e ela lhe contou, em lágrimas, que havia sido abandonada pelo primeiro marido, que decidira deixar a família para ser pai de santo, casando-se com uma filha de santo do terreiro. Ela, traumatizada, tirou o sobrenome dele dos filhos e os criou como filhos naturais do homem com quem viria a se casar mais tarde, apagando a existência do primeiro marido da vida da família. Mas ainda tinha guardado um colar dele, a única recordação que lhe restara; entregou o colar ao rapaz: era uma conta de Ogum. Tive a oportunidade de assistir à saída de santo ${ }^{2}$ desse rapaz. Sua roupa era verde-escura, indicando a qualidade de seu Ogum. O Ogum dançava devagar; era um santo velho, como me explicou sua mãe de santo. Era o santo de seu bisavô, que retornava finalmente à família. 
Muitas vezes, meus amigos de Salvador se referiam ao tipo de relação que pode acabar levando alguém a fazer o santo como enredo. "Fulano tem enredo", diz-se de alguém que tem uma relação que, em última instância, quase sempre diz respeito aos laços familiares que, por sua vez, também podem ser múltiplos e diversos, envolvendo humanos, orixás e outras entidades. Ter enredo, portanto, significa ter uma relação familiar, ancestral - seja direta ou indireta - com algum orixá; e seria então pela vontade deste que se estaria ali naquele momento. ${ }^{3}$

A utilização do termo enredo pelas pessoas do candomblé de Salvador segue muitos sentidos da palavra; porém, ao invés de significar somente um deles a cada vez, o termo tem múltiplos significados ao mesmo tempo, podendo assim dar conta dessa relação que é, por si, múltipla. Um enredo pode dizer respeito tanto a relações entre orixás quanto a relações entre seres humanos e ainda, muito frequentemente, entre humanos e orixás. Essas relações acontecem em planos de existência diversos - o que, no caso dos orixás, tanto tem a ver com os orixás "gerais", as entidades propriamente ditas (Oxum, Iemanjá etc.) quanto com os orixás "individuais", que devem sua existência, salvo raras exceções, à feitura de algum filho ou filha de santo.

No plano geral, as relações entre os orixás perpassam toda a sua mitologia. No plano individual, cada orixá feito (o que se chama de o santo da pessoa) pode ter diversos tipos de relação com outros orixás, com outras pessoas e mesmo com outras entidades não humanas. Um enredo entre dois orixás individuais, por exemplo, pode fazer com que os seus "filhos" sejam feitos no mesmo barco. Nesse caso, a iniciação concretiza uma relação (ou enredo) que, na verdade, já existiria desde antes.

As relações entre humanos e orixás também se dão tanto no plano geral (entre uma pessoa e um determinado orixá) quanto no plano individual (entre uma pessoa e um orixá individual, seja seu ou de outrem). Uma pessoa pode, por exemplo, ter enredo com Oxalá e por isso não suportar azeite de dendê. Mas pode também ter algum enredo com um Oxalá determinado, de alguém da sua família, o que geralmente demandaria algum tipo de ação mais específica.

Indaguei a várias pessoas do candomblé sobre o significado do termo enredo. As respostas foram variadas: "É uma história"; "É a história da vida de uma pessoa"; "É uma coisa de família"; "É uma ligação que você tenha", e assim por diante. "Enredo é uma palavra bem do candomblé», me disse Mãe Carmem, quando lhe pedi para definir o seu significado. "Quer dizer a história da pessoa... Mas também quer dizer as coisas todas dela, da família dela... Quer dizer um monte de coisa, e todo mundo tem um monte de enredos, cada um diferente do outro". 


\section{Voltando pra Casa}

Certa vez um amigo de Salvador me disse que "a gente sempre acaba na Casa da nossa família. Se você roda, roda e acaba numa casa jeje, é porque a sua família, lá nos primórdios, vem do Daomé. A gente sabe que o ser humano veio da África. Então todo mundo só está achando o caminho de volta pra casa". Achar o caminho de volta pra casa significa, em última instância, reconhecer o parentesco que há entre a pessoa e o orixá. Sendo o orixá um ancestral divinizado, como me explicaram inúmeras vezes, intrinsecamente ligado à terra onde viveu enquanto humano, a volta pra casa, representada aqui como uma Casa de candomblé da nação à qual pertence o local, simboliza esse reencontro, essa reconstrução dos laços de parentesco há muito desfeitos.

O Gantois é uma das Casas de candomblé - como os terreiros são comumente chamados - mais antigas de Salvador. Foi fundado em 1849 por Maria Julia da Conceição Nazaré, egressa do Candomblé da Barroquinha, que atende hoje pelo nome de Casa Branca. O primeiro registro do Gantois na literatura etnográfica foi também o primeiro relato dito "científico" sobre os candomblés publicado no Brasil. Raimundo Nina Rodrigues, um maranhense que foi estudar medicina legal e psiquiatria em Salvador e se tornou ogã do terreiro, começou lá suas pesquisas, dedicadas a provar que o transe era uma espécie de histeria da população negra, considerada por ele como intelectualmente inferior. Depois dele, Artur Ramos também fez suas pesquisas no Gantois, seguido por Ruth Landes. ${ }^{4}$ Porém, o terreiro se tornou especialmente conhecido por causa de Mãe Menininha, sua ialorixá (mãe de santo) de 1922 a 1986. Durante esse período, especialmente nas décadas de 1960 e 1970, o terreiro ganhou forte expressão popular: diversos artistas se tornaram filhos de santo (ou amigos) da casa, fazendo assim o terreiro conhecido fora do circuito das religiões de matriz africana de Salvador.

Além disso, o Gantois tem uma característica marcante: ao longo de toda a sua existência, a maioria de seus filhos de santo (incluindo aí ogãs e equedes) sempre foi de um certo número limitado de famílias. A maioria dos membros dessas famílias acabou se concentrando na pequena comunidade que se estabeleceu em volta do terreiro, formando uma espécie de compound. ${ }^{5}$ No começo, os mais antigos se mudaram para estar perto de sua mãe de santo, já que as obrigações, antigamente, eram mais longas e mais demandantes. Mas essas casas foram se multiplicando e crescendo para abrigar os descendentes dessas famílias, e hoje há mais de 60 casas de filhos de santo no entorno do terreiro, sejam lajes construídas por cima de antigas casas, ou outras casinhas que foram sendo feitas à volta das casas 
originais. Todas essas famílias, que descendem basicamente de seis antigas egbomis ${ }^{6}$ do terreiro, têm atualmente diversos membros feitos no Gantois.

No Brasil, acostumamo-nos a pensar na família de santo, em sua origem, como uma substituta natural da família de sangue: os africanos escravizados, separados à força de seus parentes consanguíneos e agrupados de maneira a serem mantidos apartados daqueles com os quais mantinham laços genealógicos de solidariedade, em seus clãs ou tribos, trataram de reconstruir simbolicamente seus laços de parentesco. Segundo me explicou um pai de santo de Sergipe que conheci:

A composição das famílias de santo era uma maneira de os escravos recriarem as suas estruturas familiares que haviam sido rompidas com a escravidão. $\mathrm{O}$ candomblé é uma criação - no seio da Igreja Católica, pois isso era necessário na época, senão seria proibido - que permitiu aos negros escravizados recriarem a sua família de sangue. Como as famílias eram sempre separadas, ainda lá na África ou aqui na chegada - se eles vissem que os escravos eram da mesma família, mandavam um para o Maranhão e o outro lá para o fim do mundo - os negros escravizados criavam uma nova família através do candomblé.

Toda a estrutura do que conhecemos como candomblé (inclusive o termo) é brasileira. Na África, cada orixá era cultuado majoritariamente em um determinado lugar, por um sacerdote ou sacerdotisa especializado(a) em seu culto. Em Oyó, cultuava-se Xangô, e lá todas as famílias têm Xangô. Assim, todos os que nasciam em Oyó eram considerados, literalmente, descendentes de Xangô. Os que viviam na margem do rio Osun, de Oxum, e assim por diante. Os orixás eram transmitidos, na maioria dos casos, por linhagem paterna, de pai para filho, geração após geração. Não havia, portanto, na maioria dos casos, a necessidade de se jogarem os búzios para saber qual era o orixá da pessoa (aliás, o jogo de búzios tal como o conhecemos hoje quase não existia; a divinação era feita pelo babalaô, através do Ifá). O orixá era, de fato, um antepassado, a que seu "filho" se achava ligado por laços de sangue.

A diáspora mudou esse regime e instaurou novas maneiras de existir para essas religiões tradicionais. Separados à força de suas famílias de sangue, ou seja, de seus orixás, os africanos mandados para o Brasil tiveram que reorganizar as bases de sua religião; "secretar a sua própria concha", nas palavras de Bastide (1972). Aqui, separados de seus familiares, e muitas vezes de todos os seus parentes consanguíneos, inventaram um novo modelo organizacional: agrupariam todos os orixás na mesma Casa, assentando juntos orixás de diferentes regiões, esquecendo uns e favorecendo outros. Dos mais de quatrocentos orixás que se supõe que existissem na África 
pré-diáspora, são cultuados no Brasil cerca de dezesseis, com algumas variações. Orixás de origem jeje, como Omolu, Nanã e Oxumarê, passaram a dividir o espaço com orixás dos iorubás, formando, eles também, uma grande família.

Além disso, se na África originalmente cada família cultuava um orixá, no Brasil essa transmissão passou a acontecer de outras maneiras. Em primeiro lugar, o papel das mulheres na religião transformou-se radicalmente: a gradual substituição da adivinhação pelo ifá para a leitura do odu (o destino pessoal) através do jogo de búzios permitiu que as mulheres, de coadjuvantes (já que os adivinhos eram sempre homens, os babalaôs, e a transmissão dos orixás acontecia, como já sublinhamos, por linhagem paterna), passassem a ser protagonistas, mães de santo responsáveis tanto pela divinação quanto pela feitura dos orixás. Se em Cuba, por exemplo, o papel dos babalaôs continuou sendo o da divinação, complementado pelas mães de santo que cumprem os rituais e fazem os trabalhos, no Brasil é a mesma pessoa, seja mulher ou homem (mãe de santo ou pai de santo), que responde tanto pela divinação quanto pelos trabalhos e feituras.

Se na África, portanto, a família de santo e a família de sangue eram a mesma, já que os orixás pertenciam a uma linhagem, sendo transmitidos, na maior parte dos casos, por descendência patrilinear, no Brasil, com a escravidão e a consequente separação das linhagens (que quando conseguiam se manter unidas no navio negreiro eram separadas à força pelos mercadores, já no seu destino, para enfraquecer a organização dos africanos escravizados), a disposição das famílias sofreu uma reformulação. Assim como os orixás advindos de diferentes regiões passaram a se agrupar sob um mesmo teto, o mesmo ocorreu com aqueles que os carregavam. Morando juntos, sob a égide da escravidão, não lhes restava outra opção senão criar novas formas de parentesco, a "família simbólica" que viria a se transformar numa característica tão distinta das religiões de matriz africana.

Essa família simbólica seria criada na feitura, tendo como seu principal núcleo o "barco de iaôs". De cada barco nascem os "irmãos de barco", categoria de parentesco ainda mais próxima que os "irmãos de santo". Feitos pela mesma mãe e pelas mesmas "mães criadeiras", os "irmãos de barco" compartilham diversas outras características: se a feitura é um renascimento, o noviço sai do sabaji (nome dado no Gantois ao aposento onde os noviços ficam recolhidos durante a iniciação) pertencendo a uma nova organização parental, a do terreiro: agora ele tem uma nova mãe, a mãe de santo; novos irmãos, os irmãos de santo; e ainda os irmãos de barco, que nasceram junto com ele, espécie de gêmeos místicos com os quais dividiram o útero materno, de que saíram no mesmo momento. 
Essa estrutura fez com que muitos autores defendessem que a família de santo é uma nova família, que vem somar-se à família consanguínea daquele que se inicia. Estudos sobre o parentesco no candomblé, com raras exceções (Halloy 2005, 2010; Goldman 2012), apontam para uma separação, ou complementaridade, entre a família de santo e a família de sangue. Vivaldo da Costa Lima, por exemplo, em seu clássico livro A Família de Santo nos Candomblés Jeje-Nagô (2003 [1977]), descreve a "família-de-santo" como excludente à família de sangue. A pessoa que faz o santo, segundo ele, ganha uma nova família, destacada da sua família consanguínea (embora semelhante a esta em seu funcionamento).

O objetivo principal do trabalho de Costa Lima é, segundo o próprio, “analisar uma relação entre o sistema empírico que é a família de santo com a família estruturada em bases direi que 'sociobiológicas' e a sociedade global em que os dois sistemas se inserem" (1977:26). Para isso, o autor entrevistou inúmeros pais e mães de santo de Salvador, concluindo, com isso, que "a linhagem de santo se opunha, assim, à família biológica, esta última raramente reconstituída na nova circunstância sociopolítica dos escravos africanos e seus descendentes no Brasil" (1976:142). Opostas, porém funcionando de maneira semelhante: ambas, para o autor, reguladas pelos mesmos princípios de interdição sexual, embora em intensidades diferentes.

Costa Lima afirma que um dos únicos terreiros onde a família de santo, denominada por ele "família classificatória", e a família consanguínea podem se "confundir" é justamente o Gantois (1977:143). O foco do autor, neste caso, é a sucessão; seu interesse está restrito à transmissão da liderança entre mulheres da mesma linhagem de sangue em que esse encontro supostamente se daria.

Creio, porém, que a questão no Gantois possa ser vista de outra maneira. Tomemos como exemplo o caso de Leila, neta de sangue de Mãe Carmem, portanto, bisneta de Mãe Menininha. Leila leva consigo, como herança familiar, a Oxum de sua bisavó. Não somente isso: além de Oxum, ela tem, na sua cabeça, Ewá - a mesma que, ao que tudo indica, também pertencia à Mãe Menininha. Os orixás individuais de Mãe Menininha, neste caso, passaram diretamente para Leila, sua bisneta, que os recebeu como herança. A linhagem de sangue e de santo se tornou, assim, uma só, e não duas superpostas, como indicou Costa Lima. Como entender, portanto, a transmissão por herança? O que exatamente é transmitido? No Gantois verifica-se uma preocupação constante com a reconstrução desses laços de parentesco, marcada principalmente pela busca de uma linhagem que seja concomitante, tanto de santo quanto de sangue. 
Vemos, desta forma, que a questão no Gantois é mais complexa do que uma "confusão" entre consanguinidade e representação simbólica. Neste terreiro específico, as famílias "de santo" e "de sangue" estão misturadas, ${ }^{7}$ o que resultou em um modelo de parentesco no qual o santo - ou, em última instância, o axé - se transmite pelo sangue. A seguir, apresentarei o caso da família de Mãe Carmem, e a transmissão por herança que lhe é característica.

\section{A família do Gantois}

Desde a sua fundação, o Gantois sempre foi uma casa "familiar": só mulheres da linhagem de sangue da fundadora podem assumir a liderança. Essa linhagem tem como característica a "herança" de orixás, ou seja, os santos de cabeça dos familiares são passados, de maneira direta, para os descendentes (como no caso de Leila, relatado anteriormente). A família teria conseguido manter a transmissão direta dos orixás, nos moldes africanos, por ser considerada "de sangue puro". Segundo me contou uma filha de santo do terreiro, "a família é considerada de linha direta de uma linhagem nobre do candomblé, pois suas raízes diretas vieram da África, enquanto nossas famílias são miscigenadas e não são de linhagem direta, e por isso precisou haver outras formas de transmissão consanguínea dos santos". Na família de Mãe Carmem, que está hoje à frente do terreiro, quando alguém morre, jogam-se os búzios para saber se o santo da pessoa quer ser despachado ${ }^{8}$ ou prefere ficar na terra.

O Gantois já foi comandado por seis mães de santo: Maria Júlia, a sua fundadora; Pulquéria, sua filha; depois de Pulquéria, Maria da Glória assumiu durante pouco tempo; e, em 1922, Mãe Menininha assumiu o cargo. Após sua morte, foi substituída pela filha mais velha, Cleusa. Quando Mãe Cleusa faleceu, sua irmã, Mãe Carmem, tomou posse como mãe de santo.

Maria Júlia, a primeira mãe de santo, era de Dada, uma qualidade de Xangô. Porém, o axé do terreiro, o conjunto de elementos enterrados embaixo de um quadrado bem no meio do salão, o assentamento fundamental da Casa, é de Iya Massê, a mãe de Xangô (que dá nome à Casa). Embora o primeiro orixá de Maria Júlia fosse Dada, ela somente recebia Oxaguiã. ${ }^{9}$ Já Pulquéria era de Oxóssi. Mãe Menininha era de Oxum, e Mãe Cleusa, de Nanã. Mãe Carmem, por sua vez, é de Oxaguiã. E, segundo ela me explicou, o seu Oxaguiã é o mesmo de Maria Júlia, a fundadora do terreiro ${ }^{10}$ - os outros orixás se espalharam pelos membros da família consanguínea. ${ }^{11}$

Certa vez assisti a um discurso da mãe pequena da Casa, filha consanguínea de Mãe Carmem, no qual ela chamava a atenção justamente 
para o fato de a linhagem do Gantois ser "direta", ou seja, uma sucessão de mulheres que, "com práticas milenares das antigas sociedades de linhagem e historicamente de tradição familiar hereditária, consanguínea, e matriarcal", estabeleceram uma Casa de Candomblé baseada nos fundamentos da "ancestralidade africana". Ainda segundo uma filha de santo do Gantois, "em famílias ligadas pela linha consanguínea e de axé, os 'orixás retornados' são mais comuns, pois são oriundos de espécies de realezas africanas".

Arnaud Halloy (2005) propôs para a análise do candomblé um sistema em que coexistem duas formas de transmissão do saber, ou seja, duas formas de aprendizado: a consanguínea, chamada por ele de "modelo biológico", e a transmissão por participação, denominada "modelo culturalista". No entanto, o autor chama sempre a atenção para a complementaridade entre estas duas formas de aprendizado. O primeiro modelo é restrito à família de Pai Adão (o fundador do terreiro onde ele fez sua pesquisa, no Recife) e seus descendentes diretos. Estes, segundo Halloy, dizem que "nasceram feitos", necessitando somente de um "complemento" para ficarem prontos a receber seus orixás e tornarem-se um filho ou filha de santo da Casa. No Gantois ouvem-se histórias muito parecidas com as que Halloy recolheu em Recife. "O sangue não vira água"; "Isso aí vem no sangue"; "Esse enredo é de sangue", além de muitas vezes se referirem à família de Mãe Carmem como de "sangue azul".

No Gantois, porém, em momento algum se supõe que os membros da família das mães de santo estejam dispensados de passar pelos ritos de iniciação. Lá não se observam exceções como as registradas na família de Pai Adão. Todos devem se submeter igualmente aos rituais de feitura, embora possa haver pequenas diferenças e particularidades no caso de um orixá de herança. Van de Port (2005) sugeriu o contrário, citando o caso de Leila, a neta de Mãe Carmem que não teria raspado o cabelo quando se iniciou, insinuando ter ouvido rumores de que os membros da família gozariam de privilégios durante a feitura. No entanto, segundo me explicou a própria Leila, a qualidade de sua Oxum não demanda a raspagem total da cabeça; ela ficou, em suas próprias palavras, "como um pica-pau", pois teve que raspar as laterais e o topo da cabeça. Além disso, como vimos, seu orixá é "retornado", o que impõe certas especificidades a todo o processo de feitura.

De todo modo, o que fica implícito no modelo proposto por Halloy é a possibilidade da transmissão do saber através do sangue. Embora no Gantois isso não seja dito em relação à transmissão do aprendizado - e o método de ensino, mesmo para os membros da família, seja mais parecido com o que Goldman (2003) denominou "catar folha" - fala-se o tempo todo, como citei no começo deste texto, que são as relações familiares (ou seja, consanguíneas) que levam alguém a fazer parte do candomblé. 
"O sangue não enfraquece", falou a outra filha consanguínea de mãe Carmem, Iyadagan do terreiro, referindo-se a uma criança que acabara de dar os primeiros sinais de que precisava ter seu santo assentado. O pai da criança, ao lado, concordava: sendo filho e neto de homens feitos no Gantois, era muito provável mesmo que o menino também necessitasse da feitura em algum momento de sua vida. Mas por quê? Segundo ela me explicou, isso "está no sangue". Goldman (2012) sugere que os dados de Halloy (2005) indicam, em lugar de um modelo de transmissão do saber dividido entre sangue e convivência, ou seja, a transmissão por herança ou aprendizado, um modelo triádico, em que um terceiro termo, a participação, também precisa ser levado em conta. E tanto em sua acepção propriamente ritual, isto é, no que diz respeito à convivência cotidiana no terreiro, quanto no sentido que lhe atribui Bastide (1958): "Entrar em relação, material ou não, com aquilo que constitui o ritual" (Goldman, 2012:9). Assim, ainda segundo Goldman (2012:10), “a 'transmissão por participação' diz respeito tanto ao que se aprende enquanto membro de um terreiro quanto ao que se recebe na iniciação propriamente dita".

De acordo com Elbein (1975), o sangue é o veículo principal do axé. É através dele que flui a energia que alimenta os orixás e as pessoas, conectando uns aos outros. É através do sangue derramado na cabeça do noviço que se estabelece a maternidade ou a paternidade ritual, de santo. É necessário catular, ou seja, abrir um furo no couro cabeludo do noviço, para que o sangue do animal entre em contato com o sangue da pessoa e essa maternidade ou paternidade possa enfim se concretizar. O sangue, no candomblé, é um elemento conectivo (cf. Goldman 2012; Elbein 1975). Conecta planos e realidades distintas para permitir o fluxo de vida, de axé. É através dele que o axé é transmitido e que circula entre os seres humanos e entre os humanos e os orixás - isto é, entre os dois planos da existência, o aiyê e o orun. E é também através do sangue que se misturam as histórias, já que no candomblé características externas podem tornar-se parte da vida das pessoas e dos orixás, de tal maneira que um se torna parte do outro. Mas a questão cresce em importância se pensarmos que o sangue do sacrifício, veículo maior do axé, transmissor interpessoal (e interespécies) de energia vital, é em última análise o mesmo sangue da transmissão consanguínea, ou seja, o veículo da transmissão hereditária entre pais e filhos.

Se no caso da família de Mãe Carmem os orixás são transmitidos através da "herança", o mesmo não acontece com os membros da família Cajazeira, uma das mais antigas a se instalar no entorno do terreiro. Nessa família, a transmissão "genética" (como eles mesmos se referem) ocorre de outra maneira: é a relação com os espíritos que passa tanto para as 
pessoas quanto para os orixás da família, em um complexo modelo que tentarei descrever a seguir. Mas, antes, apresentarei brevemente algumas observações sobre a noção de pessoa no candomblé para tornar mais claro o meu argumento.

\section{Sobre a noção de pessoa no candomblé}

Na literatura existente sobre a noção de pessoa no candomblé, é recorrente o uso do modelo arquetipal, para o qual os orixás corresponderiam na verdade a arquétipos de personalidade humana, moldes aos quais a pessoa deve sua forma e a eles se limita. A identificação de cada indivíduo com um orixá aplacaria os conflitos internos de sua própria personalidade, que assim se encaixaria num modelo preexistente representado ao limite nos rituais de possessão. Marcio Goldman (1984) inovou a discussão argumentando que os orixás, em vez de modelos de personalidade, são, eles mesmos, partes da pessoa.

Segundo Goldman, a pessoa no candomblé é formada ao longo de sua feitura, de acordo com as entidades que vão sendo incorporadas à sua cabeça. No terreiro de nação angola estudado por Goldman, trata-se de sete orixás, mais um erê, um egum e um exu. No Gantois, essa composição não é tão rígida, mas o processo de formação da pessoa é exatamente o mesmo. A cada obrigação (de um, três, sete, 14 e 21 anos), acrescenta-se mais algum componente à pessoa - embora a manipulação da cabeça possa ser levada a cabo a qualquer momento, e há casos em que não se acrescentam novas entidades, mas apenas algo relativo àquelas já assentadas na feitura.

Voltemos ao caso de Leila, a neta de Mãe Carmem. Ela assentou (ou seja, criou um duplo concreto para) a sua Oxum (que vinha da sua bisavó) ainda criança. Alguns anos depois, começou a "passar mal" (como se diz no Gantois quando há o início de possessão pelo santo ainda bruto), algumas vezes, nas festas. Logo, Mãe Carmem viu nos búzios que a sua Oxum queria ser feita. Ela então se submeteu à feitura. Alguns anos depois, na véspera da sua obrigação de três anos, começou a sentir a presença ocasional de outro orixá querendo tomar sua cabeça. Ela então pediu à mãe Carmem que jogasse os búzios, o que revelou a existência de "um enredo complicado", como ela me falou, com Ewá (que, como descobriram depois, também vinha de Mãe Menininha). Assim, quando Leila se recolheu para a sua obrigação de três anos, assentou Ewá e, a partir daí, em alguns momentos

é Ewá quem chega. "Vamos ver quem é que vai aparecer para a minha obrigação de sete anos", ela me disse, brincando. 
Essa brincadeira, porém, evoca uma importante reflexão sobre a concepção de pessoa corrente no candomblé. Cada história, cada relação, cada enredo tem sempre o potencial de lhe acrescentar um novo elemento - que pode ou não demandar uma representação física. Isto não significa que a pessoa estava incompleta: dependendo do ponto de vista, no candomblé, a pessoa, que é fluida, está sempre completa, ou sempre incompleta. Ao contrário do que pode parecer, o ritual de iniciação no candomblé não resulta em duas individualidades indiferenciadas: a do filho de santo e a de seu orixá. Muito pelo contrário, a feitura, concretizando as relações entre o santo e seu filho/sua filha, é o cimento que permite a criação do amálgama pessoa-orixá. Como vimos, toda feitura é acompanhada de um assentamento; ao mesmo tempo, no caso de um adoxu, sua cabeça é preparada para que o santo chegue através de um furo aberto em seu couro cabeludo (a catulagem). A conexão entre a cabeça do noviço e o assentamento que representa o seu orixá é estabelecida quando ambos são banhados com o mesmo sangue. Na criação desse duplo cabeça/assentamento, constitui-se um enredo que adquire uma expressão concreta.

\section{Transferências e manipulações}

Em Salvador, tive a oportunidade de acompanhar de perto algumas feituras, dentre elas a de um rapaz que morava no Rio de Janeiro e fez santo em um terreiro cuja ialorixá era feita no Gantois. Como ele trabalhava, organizou suas férias para coincidirem com seu período de recolhimento. Passou um mês no terreiro, ao fim do qual foi liberado para voltar para casa, o que incluía uma viagem de avião e o reencontro com sua esposa. Perguntei à mãe de santo se ele podia pegar um avião sem problemas com tão pouco tempo de feito, e ela respondeu: "Pode sim, eu que vou cumprir esse resguardo. Ele é jovem, precisa viajar, trabalhar, namorar a mulher dele... Eu já estou mais velha, não vou sair daqui mesmo, então vou cumprir o resguardo por ele". Depois, quando acompanhei uma moça francesa que assentou o santo, uma Iemanjá, com essa mesma mãe de santo, a situação se repetiu. Quando ela foi liberada, depois de uma semana de recolhimento, fui buscá-la. Assim que cheguei ao terreiro, ela me disse que queria tomar um banho de mar e uma cerveja. Traduzi para a mãe de santo o que ela dissera, e ela me respondeu, depois de pensar um pouco: "Pode ir, pode levar ela". "Mas como?", perguntei, e ela então me respondeu. "Eu que vou fazer o resguardo dela, ela é francesa, e francês lá entende dessas coisas, minha filha?". 
No candomblé, as fronteiras da pessoa são fluidas, o que permite diversos tipos de transferência. Como a pessoa está sempre em formação, isto a deixa permanentemente aberta ao que vem de fora. Depois que ela é feita, porém, passa a contar com um filtro que só dá passagem às coisas certas (condizentes, portanto, com seu enredo), que se acoplam a ela. E são as fronteiras fluidas que permitem essas transferências. Depois que a pessoa é feita, o que ocorre é uma diferença quanto ao que pode ser transferido, e com qual intensidade. A partir dessa concepção de corpo, torna-se possível manipular as fronteiras da pessoa e entender essas transferências, rotineiras no candomblé.

O momento da feitura, quando o barco de iaôs está recolhido no sabaji, é o mais delicado na formação das pessoas. Nessa hora, muita coisa pode passar de um para o outro: os canais estão abertos, o controle dos fluxos é ainda incipiente. É comum ouvirmos relatos de quizilas que passam de um iaô para o outro, especialmente se estão deitados lado a lado (já que o barco de iaôs sempre mantém a mesma formação, até na hora de dormir).

Mas a transferência também se dá entre orixás. Uma vez, já de volta ao Rio, fui a uma festa de Xangô num terreiro em Niterói com um amigo, adoxu de Oxaguiã. No meio da festa, começaram a tocar para seu santo e vi que ele ficou nervoso. Não queria dar santo, me explicou. Não era o terreiro dele, não se sentia à vontade, não queria dançar. Enquanto ele me explicava, o Oxaguiã de uma filha de santo da casa chegou. Quando ele viu o santo dançar, tranquilizou-se imediatamente. "Esse santo é da mesma qualidade que o meu" - ele me disse. "Posso ficar tranquilo, então, que não vou precisar dar santo". Ou seja, o fato de haver no salão um orixá semelhante ao seu (da mesma qualidade, no caso) liberava o orixá dele da obrigação de comparecer. "Ele já está ali representado", ele me explicou. "Na verdade, é como se um pedaço dele estivesse ali, ou melhor, como se ele mesmo já estivesse ali".

A fluidez da pessoa dá margem também a manipulações, dentre as quais a mais conhecida é a substituição do santo da cabeça da pessoa. O exemplo mais comum deste tipo de substituição acontece quando uma pessoa que é de Exu precisa fazer o santo num terreiro onde não se faz Exu (caso do Gantois). Nessas situações, a pessoa tem duas opções: ou procura um terreiro onde se faça Exu (se houver espaço para isso, claro), ou pede à mãe ou ao pai de santo de seu terreiro que manipule a composição de sua cabeça de maneira a lhe permitir ser feito ali mesmo. A solução mais comum para este caso é fazer Ogum Xoroquê, a qualidade de Ogum "que mais tem enredo com Exu", ou "que é quase Exu", ou é a "mais próxima de Exu". Assim, Exu fica satisfeito, "mas não muito", como me explicou uma mãe de santo. "A gente consegue controlar ele, mas quem vem é Ogum Xoroquê". E 
como Ogum Xoroquê está tão próximo a Exu, este pode receber os devidos cuidados através de seu semelhante.

As substituições e as manipulações nunca ocorrem sem critério, pelo contrário, seguem uma lógica refinada e difícil de ser apreendida. Há diversos desvios possíveis no caminho que precisam ser considerados pela mãe ou o pai de santo que se propõe a este tipo de operação. Outro caso de manipulação é o de Obaràyí, um pai de santo muito conhecido de Salvador. Obaràyí nasceu de Ogum mas, na hora da feitura, Xangô é que foi feito. A explicação, dada pelo próprio Obaràyí (2009), é que seu Xangô não é um Xangô novo (apesar de ser da qualidade mais jovem de Xangô, Aganju): é o Xangô de Mãe Aninha, a célebre mãe de santo do Ilê Axé Opô Afonjá. Ele, que havia avisado que retornaria, veio para a sua cabeça, determinando a reformulação de sua feitura - segundo Obaràyí, "por um bom motivo" (2009:96).

Mas voltemos à história da outra família que pretendo apresentar, na qual essas transferências ocorrem de modo diferente: ao longo das gerações, incorporando-se ao sangue que é transmitido aos descendentes de Seu Carlos Cajazeira, um famoso médium que morava ao lado do terreiro do Gantois.

\section{A família Cajazeira}

Os membros da família Cajazeira habitam o entorno do Gantois há pouco mais de cem anos. O primeiro a chegar foi Seu Carlos Cajazeira, tataravô dos mais novos membros da família que conheci, que aos 20 anos comprou uma das únicas casas que havia à venda na pequena rua de terra do Alto do Gantois, a uns 50 metros do terreiro. Seu Carlos Cajazeira foi morar nos arredores do Gantois por acaso. Havia uma boa casa à venda ali e ele, que era mestre de obras, mudou-se para lá com a família. Tinha 21 anos quando foi morar no Alto do Gantois; a mãe de santo, na época, era Pulquéria. Logo Seu Carlos se casou e sua esposa, assim como ele, era médium. Com o tempo, a mediunidade dos dois se tornou mais forte e os espíritos exigiram que eles fizessem em sua casa uma mesa branca, nome que se dá, na Bahia, a sessões espíritas domésticas que acontecem geralmente uma vez por semana (segunda-feira, no caso de Seu Carlos). As sessões de mesa branca caracterizam-se pela grande variedade de espíritos que nelas se manifestam, e a de Seu Carlos não era exceção: numa mesma sessão, podiam aparecer orixás, espíritos de médicos, como João Luiz, caboclos, astecas, exus e mais uma ampla variedade de entidades - desde as entidades "sem luz", que causam problemas na vida das pessoas e podem assumir formas diversas, 
até os espíritos "de luz", normalmente espíritos de médicos, curandeiros etc., que vêm à Terra a fim de prestar auxílio em tratamentos e processos de cura. Seu Carlos trabalhava também no combate ao "encosto", livrando a pessoa das influências maléficas do espírito que trazia "encostado".

Havia entre Seu Carlos e o Gantois o que uma de suas filhas definiu como uma "divisão de trabalhos". Quando percebia que a entidade que havia chegado era um orixá ou um caboclo ("da parte de azeite", ${ }_{1}^{12}$ como ela me falou), encaminhava para o terreiro, na época já comandado por Mãe Menininha. Por outro lado, quando no Gantois chegava uma pessoa com problemas "de espírito", era direcionada para a casa de Seu Carlos.

Ao mesmo tempo em que o candomblé e o espiritismo se fundiram na criação da umbanda, a "única religião brasileira" no dizer de Bastide (1971), mantiveram, em paralelo, essa relação complementar que até hoje se pode observar em diversas Casas. Halloy (2005) afirma que o candomblé tomou de empréstimo certos conceitos do espiritismo para descrever fenômenos que vieram com essa mudança infraestrutural. ${ }^{13}$ Como lidar com a reencarnação, agora que as linhagens não podiam mais manter-se puras? Segundo um amigo de Salvador me explicou, o problema não é somente de linguagem: para ele, o candomblé acoplou a seus princípios alguns fundamentos da doutrina espírita para suprir determinadas lacunas, explicação que leva em conta o caráter agregador do candomblé, que engloba e acrescenta a seus princípios as ideias mais adequadas às suas necessidades, que desse modo se incorporam a seu arsenal de recursos.

A maioria dos descendentes de Seu Carlos Cajazeira teve "questões de santo", acabando por serem encaminhados ao Gantois. Cada um destes santos da família de Seu Carlos, no entanto, tem características muito específicas. Ao invés de sua transmissão se dar de maneira direta, como é o costume no espiritismo (o espírito que acompanhava Seu Carlos passaria, depois de sua morte, a acompanhar os seus descendentes), foram outros os mecanismos que entraram em ação.

O primeiro membro da família Cajazeira que conheci foi Yohanna. Ela tinha, na época, 28 anos e é de Iemanjá. Ela fez santo aos 9 anos, uma coisa rara no Gantois, onde geralmente se espera que a criança tenha 12 anos completos para submetê-la à feitura. O caso de Yohanna era grave, me explicaram. Ela certa vez me contou que sua feitura foi complicada e demandou um vasto conhecimento por parte da mãe de santo; além disso, para completá-la, precisou circular por vários terreiros, entre eles um terreiro de egum. Quando lhe perguntei sobre o porquê, ela me contou a história de seu avô. Por ele ter sido um mestre da mesa branca, ela havia herdado essa relação com os espíritos, e seu enredo com os mortos era muito 
forte. Yohanna também me falou sobre alguns detalhes de sua feitura. As primeiras manifestações de seu orixá foram, como me explicou, um "transe de morte". "Eu ficava branca, fria, com a boca roxa, por várias horas", ela me disse. "Demorou para eu fazer o santo, porque era complicado, e eu era criança, aí eu tive isso várias vezes, tipo uma catalepsia".

Mas a primeira pessoa da família a fazer o santo no Gantois foi Cleide, filha de Seu Carlos. Sua história me foi contada por Dona Leda, a filha mais velha de Seu Carlos: "Cleide era de Omolu, o Omolu doente, do cemitério". A primeira manifestação de que Cleide precisava entrar para o candomblé foi quando ela viu Omolu, "um velho com uma bengala e um cachorro lambendo as feridas dele", na Gruta de São Lázaro. Depois de algumas visões do tipo, sua mãe levou-a para Mãe Menininha, que diagnosticou: Cleide era de Omolu, de uma qualidade específica, e ele queria ser feito. A feitura foi levada a cabo por Mãe Menininha, mas com a ajuda de Seu Carlos. "Devido a ter essa coisa de espírito, Mãe Menininha mandava pra lá e candomblé mandava pra cá, então ficou essa relação".

Quando eu conheci a família Cajazeira, Cleide tinha acabado de morrer. Segundo Dona Leda, sua irmã, ela foi aos poucos abandonando a religião:

Ela teve nove filhos. Tem três mortos. Morreu um que se jogou do viaduto com 30 e poucos anos. O segundo, que era meu afilhado, também se jogou do viaduto uns anos depois. Aí nessa coisa ela entrou pra igreja, desacreditou de tudo, começou a entrar no evangélico, depois começou a falar um bocado de asneira, que nem Deus existia, que não sei o quê, que não tem santo, não tem Deus. E essas coisas vêm passando. Ela aí ficou dez anos cuidando dele, meu afilhado. Depois ele morreu. Fez um ano. E agora Cleide morreu também. Aqui na minha família o enredo com morte é muito forte. Não pode ficar achando que tudo bem largar. Tem que cuidar, sempre, por causa do meu pai. Passou para todo mundo.

A segunda pessoa da família a entrar para o candomblé foi Miralva, também filha de Seu Carlos. Miralva é de Iansã e, desde as primeiras manifestações, ficou claro que sua santa tinha características bem específicas. Assim como Yohanna, seus primeiros transes foram "de morte". Sua irmã Leda a encontrou no banheiro, segundo ela me contou, "semimorta":

Acho que o meu anjo de guarda me acordou na hora, porque quando eu levantei, quando eu cheguei lá, ela estava mais do que morta. O corpo todo, cerrou tudo, os dentes, as unhas, tudo arroxeou. Foi morte mesmo. Isso foi duas e pouco da noite, ela voltou oito e pouco da manhã. E essa foi só a primeira de muitas. 
Miralva, porém, não gostava de candomblé, e se recusava a fazer o santo. Numa dessas crises catalépticas, foi parar em um médico que, depois de fazer todos os exames, lhe recomendou enfaticamente procurar ajuda espiritual. Miralva finalmente aceitou se submeter à feitura, porém o processo foi diferente de uma feitura tradicional: ela teve que ir a sete casas de candomblé e a uma especializada em egum a fim de completar as especificidades de seu processo. Para sua irmã:

Ela é de Iansã do Balé. Porque a santa dela tem essa relação com a morte, e também com a mesa branca. E a santa dela, como Mãe Menininha mesmo disse, comunica mais com egum do que com santo. A santa dela só se traja de branco. Mãe Menininha disse que a santa dela mora na torre do cemitério, na igreja do cemitério. Ela não pode nem visitar doente, que se ela for visitar, o doente piora. Às vezes vai embora mesmo. Começou com alguns dos nossos parentes. E ela mesmo vê, se ela for ver um doente e o doente já estiver ruim pra morrer, ela vê o espírito do lado da pessoa, já não vê na pessoa. E o espírito desencarna e vai em cima dela.

De acordo com Dona Leda, todos os descendentes de seu pai, que são médiuns, em vez de continuarem na mesa branca, foram para o terreiro. Mas a questão espiritual ficou marcada no tipo de relação que cada um tem com o seu orixá, e na história de cada orixá - já que todos os orixás de seus descendentes que fizeram o santo têm um enredo com a morte e com os espíritos, tanto por serem de qualidades já ligadas a isso (Iansã do Balé, por exemplo, ou Omolu do Cemitério) quanto pelo fato de todas as mulheres da família cujo orixá quer ser feito apresentarem um transe que se assemelha à morte. De alguma forma, é como se essas entidades espirituais que acompanhavam Seu Carlos continuassem por perto, mas a maneira de permanecerem é se associando ao orixá, absorvendo essas relações, essas histórias.

Quando Dona Leda fala que a Iansã de sua irmã tem enredo com a morte, ou com os espíritos, quer dizer, em última instância, que a Iansã dela tem relação com a morte, ou mesmo é a morte, e que traz a morte para os doentes que dela se aproximam. Não é uma Iansã que ande acompanhada por um espírito: é uma Iansã que tem, em sua história (ou melhor, no conjunto de histórias que formam a sua história), enredo com os mortos ou espíritos, ou seja, os espíritos e a morte fazem parte dela. A morte, os espíritos, continuam próximos, mas não de maneira autônoma. Outro exemplo deste tipo de relação é o orixá de Yohanna, uma Iemanjá que tem enredo com egum, os espíritos dos mortos, e cuja feitura precisou ocorrer, em parte, num terreiro de egum, justamente porque esses espíritos fazem parte da Iemanjá dela, isto é, esse componente é parte da sua Iemanjá, mas decorre de uma 
relação, de uma história. Porque o enredo é uma história, é uma narrativa, mas é, acima de tudo, uma relação. E, enquanto relação, é singular e plural ao mesmo tempo - porque são várias as histórias que compõem a história, vários os enredos que compõem o enredo, e é nesse enredo composto que a pessoa se forma. E tendo isso em mente, podemos pensar: o que, então, é transmitido? Talvez uma solução que pareça óbvia, e que me foi sugerida, seria pensar na relação do espírito tanto com a pessoa quanto com o orixá que ele acompanha como de aliança. Mas não era isso que me dizia Dona Leda: ela insistia que o espírito passou a fazer parte do orixá e de sua filha, que modificou a essência e o modo de funcionamento destes.

Creio que Dona Leda afirma que o que se transmite, neste caso, é a relação. É a relação, ou o enredo, com os espíritos que compõe a Iansã de Miralva, e a própria Miralva. Pois Miralva, assim como sua Iansã, tem enredo com a morte. E esse enredo se origina na história do patriarca da família, Seu Carlos, e a partir dele se entremeia, e se entranha, por transmissão consanguínea. Tanto que Miralva, por exemplo, nasce com essa Iansã, formada a partir dessas relações. E o que é mais importante, essas relações não poderiam acontecer em outro lugar: são específicas das formas de relacionamento do candomblé, em que as relações que se mantém com alguém ou alguma coisa são equivalentes a ser um pouco essa pessoa ou essa coisa, a tornar o objeto da relação parte de si mesmo.

Neste caso, voltando ao modelo já mencionado de Halloy (2005), poderíamos pensar que ocorre uma confluência: a Iansã de Miralva tem relação com os mortos porque seu pai convivia com os mortos, ou porque os mortos estão no seu sangue? O que este exemplo parece demonstrar é que, com o tempo, as relações são absorvidas pelo sangue - migrando da esfera da convivência para a genética, digamos assim.

Ao final do relato de Dona Leda sobre a história da sua família, ela me contou que certa vez, conversando com uma moradora da vizinhança, mais idosa, ela lhe contou que um antepassado seu, que ela não havia conhecido e de cuja existência nem sabia, também havia sido de candomblé. E foi a partir dessa ligação que Dona Leda entendeu o enredo de sua família. Ela estava comentando com sua vizinha como na sua família havia vários membros feitos no candomblé, ao que a senhora lhe disse: "E você sabe, por causa dessa ligação de seus pais com a mesa branca, por que se misturou com o candomblé? Se seus pais eram espíritas, por que vocês estão dentro do candomblé?". Dona Leda então lhe respondeu que não sabia o motivo. A senhora então insistiu: "Não tinha ninguém na sua casa que era do candomblé, não?". Dona Leda negou mais uma vez. "É aí que você se engana", a senhora lhe disse, "A parte dos seus avós, da parte do seu pai, tinha um 
tataravô que tinha uma casinha de candomblé ali na Garibaldi. Ele morreu, nessas alturas deixou de mão, ninguém assumiu. E hoje, como vocês estão todos dentro do candomblé, então tem fundamento". Dona Leda me explicou:

Então já tinha que fazer isso pra poder dar continuidade ao que ele deixou. Entendeu? Por isso que ficou essa ligação, muita gente espírita no candomblé, e esses orixás todos desse jeito, com esse enredo. Misturou tudo. A gente pegou esses espíritos, levou pro candomblé que já era do meu tataravô, aí os orixás todos, e a gente também, tem esse enredo todo com os espíritos, que passa de pai pra filho, né?

Pelo relato de Dona Leda, fica claro que o que é transmitido pelo sangue é a relação com os espíritos. Como ela conta acima, as pessoas de sua família que se submetem à feitura no candomblé não têm, em suas cabeças, um espírito ao lado de seus orixás (ou santos): o espírito é uma parte de seus orixás e, consequentemente, uma parte delas. A relação que Seu Carlos Cajazeira tinha com os espíritos acoplou-se de alguma forma a todos os orixás das gerações subsequentes, tornando-se parte deles.

\section{Conclusão}

Certa vez, eu conversava com Dona Cici, uma famosa griô (contadora de histórias) de Salvador sobre a questão do parentesco no candomblé, e ela me falou: "A nossa genética está ali dentro. Se você quiser falar de DNA, essas coisas, aí são os brancos que vão explicar, porque a gente explica desse jeito". Outra amiga, filha de santo do Gantois, referindo-se a uma família em que quase todos os membros têm Ogum, me disse que "Ogum está no sangue daquela família. Está no DNA espiritual deles. E esse DNA está junto do DNA biológico, ou seja, a família de sangue é um reflexo de uma família espiritual. Na verdade, é tudo genético, até para nós que não somos afrodescendentes diretos".

A afirmação desta amiga, "é tudo genético", traz à tona questões fundamentais acerca do parentesco no candomblé. Ainda que, como vimos, o sistema de linhagens dos orixás tenha sofrido mudanças, não permitindo mais a atribuição direta do orixá como antepassado (e, portanto, parte) de seus descendentes, não houve um abandono, ou uma substituição por uma família simbólica, como parecem crer alguns autores. Ao invés disso, instituiu-se um novo sistema de parentesco, em que o sangue é não somente o elemento transmissor fundamental, mas também o elemento conectivo das relações, formando e sendo formado por elas ao longo do tempo. Mas não apenas isso: 
a lógica das transferências e das manipulações se insere no mesmo registro; fluxos circulam por entre as pessoas e as coisas, incorporando as relações e passando-as adiante. Assim, os irmãos de barco "trocam" quizilas e a mãe de santo pode cumprir o resguardo pelo seu filho.

Como vimos, a pessoa, no candomblé, é um conjunto de suas relações (seus enredos), cujos equilíbrio e completude são sempre efêmeros. A pessoa se forma diacronicamente, mas a sua completude é sempre sincrônica completa-se num momento para descompletar-se logo depois. E ter enredo é ser parte de alguma coisa, e ter em si uma parte dela, ou seja, estabelecer com ela uma comunhão de substâncias, é possuir uma relação de parentesco, é carregar consigo um pouco do outro. Há, entre pessoas, orixás, entidades e coisas fronteiras que são fluidas, e que podem ser atravessadas com a tecnologia adequada. Todos esses exemplos tratam de uma questão fundamental do candomblé para a qual eu gostaria de chamar a atenção: o candomblé traz em sua cosmologia uma fórmula de relação em que o ser e o estar não estão separados. Assim, ter em si parte do outro, estar no outro, ser o outro são como uma linha analógica de intensidades, dosadas de acordo com a pessoa ou a situação.

Busquei ao longo do texto apresentar situações etnográficas em que o tipo de parentesco que encontrei no terreiro do Gantois pudesse ser reconhecido. Porém, como ressaltei na introdução, trata-se mais de uma "abertura de caminhos", para usar um termo caro ao candomblé, do que de alguma conclusão definitiva.

Recebido em 21/06/2018

Aprovado em 05/10/2018

Clara Flaksman

Doutora em Antropologia Social pelo PPGAS/Museu Nacional e atualmente realiza pós-doutorado na mesma instituição, sendo bolsista da Fundação de Amparo à Pesquisa do Estado do Rio de Janeiro (Faperj). Dedica-se sobretudo a pesquisas sobre as religiões de matriz africana no Brasil, com foco em temas relacionados à noção de pessoa e ao parentesco. 


\section{Notas}

1 Nas palavras de Bastide, "Diríamos, pois, que o que constitui o princípio de individuação nessa filosofia afro-baiana é a história do indivíduo. E são essas histórias em justaposição, que se entrelaçam, que se correspondem, mas que permanecem sempre autônomas, que compõem a sociedade. Trama na qual correm mil fios, cada fio tendo sua cor diferente" (1958: 147).

2 Quando alguém faz o santo, depois de uma semana de recolhimento é necessário que o novo orixá seja apresentado publicamente. A isso se chama saída de santo (pública, pois depois de três dias de recolhimento há uma saída "interna", restrita aos filhos de santo do terreiro e à família do iniciado): nesse dia, o santo deve dar o nome, ou seja, apresentar-se. Depois dessa cerimônia, o noviço volta para o recolhimento, lá permanecendo ainda por cerca de três semanas.

3 Uma breve explicação sobre a etimologia do termo: "rede" está na origem de "enredar", por sua vez a origem de "enredo". Que primeiro é o ato ou o efeito de enredar, ou enredar-se: cair na rede, tecer uma rede, organizar uma rede. Depois, desenvolve-se em paralelo uma gama de sentidos positivos: trama, argumento, sucessão de episódios; e outra, de conotação negativa: mistério, segredo, intriga, captura - por analogia à presa capturada na teia de aranha, por exemplo. O substrato comum aos dois significados é a transformação do fio em rede, ou do efeito de quem se vê preso (enredado) nessa trama ou teia. Assim, o fio da narrativa vai se combinando, por uma série de laços ou nós, num enredo, urdindo-se a trama de um tecido mais complexo.

4 Castillo (2008) defende que o Gantois foi o terreiro preferido pelos estudiosos até a década de 1930, quando a preferência dos pesquisadores recaiu sobre o Ilê Axé Opô Afonjá, preferência que, segundo a autora, mantém-se firme até os dias de hoje.

5 O entorno do terreiro do Gantois foi também o local onde Franklin Frazier e Melville Herskovits desenvolveram suas pesquisas sobre a família afro-brasileira. De acordo com Sansone (2012), no início da década de 1940, Salvador tornou-se palco de uma disputa entre dois entendimentos acerca da integração racial. Frazier (1942) e Herskovits (1943), ambos engajados na luta antirracista, chegaram a conclusões opostas em relação ao modelo de família que encontraram: para o primeiro, tratava-se de uma estrutura familiar condicionada pela situação de escravidão e de adaptação à pobreza; e, para o segundo, da sobrevivência de um padrão familiar característico da África Ocidental. Os membros da família Cajazeiras com os quais convivi não guardavam recordação da passagem dos pesquisadores norte-americanos, o que me leva a supor que não tenham participado de entrevistas nem com um e nem com o outro.

6 Filhas de santo que já cumpriram as obrigações relativas aos sete anos de feitura.

7 O que é um fato comum em muitos terreiros de candomblé aparece, neste caso, em uma dimensão ampliada, já que se trata de um dos maiores terreiros de Salvador. 
8 Despacho, neste caso, significa o processo de "desfeitura" da pessoa e do orixá, que se dá durante o axexê.

9 Sobre isso, ver também Castillo (2017:42).

10 Serra (1978:13) fala sobre os santos de herança: "Um tal santo pode ser herdado: quando morre um 'feito' ou 'feita', realiza-se o jogo divinatório para saber se deve despachar-se, confiar a alguém ou manter no Ilê Axé o 'Anjo da Guarda' assim materializado".

11 Goldman (2012:7) também escreveu sobre os santos de herança, citando o famoso caso de Joãozinho da Gomeia: "Nesse mesmo campo parecem se localizar os casos chamados de 'santo de herança', ou seja, divindades 'já prontas' ou já 'feitas' que são transmitidas a um descendente, ou mesmo a pessoas apenas próximas, após o falecimento do transmissor. Este era, por exemplo, o caso de Joãozinho da Gomeia que, além de sua própria divindade, herdou o orixá de sua madrinha, cujo assentamento ele se orgulhava em apresentar, dizendo que 'esse orixá tem 94 anos' (Cossard 1970:140)".

12 "De azeite" é uma maneira coloquial para falar que é do candomblé ("azeite", em Salvador, é o azeite de dendê). O azeite de oliva comum, como chamamos aqui, lá é denominado "azeite doce".

13 Segundo Halloy (2005:147): “(...) a maneira de conceber os eguns e os 'espíritos' é, em geral, fortemente influenciada pelo espiritismo kardecista." 


\section{Referências bibliográficas}

BASTIDE, Roger. 1958 [2000]. O Candomblé da Bahia: rito nagô. São Paulo: Companhia das Letras. 1971. As religiões africanas no Brasil (Vols 1 e 2). São Paulo: Editora da Universidade de São Paulo.

1972. Estudos Afro-brasileiros. São Paulo: Editora Perspectiva.

CARSTEN, Janet. 2000. "Introduction: cultures of relatedness". In: (org.), Cultures of Relatedness: New Approaches to the Study of Kinship. Cambridge: Cambridge University Press. pp. 1-36.

CASTILlO, Lisa Earl. 2008. Entre a oralidade e a escrita: A etnografia nos candomblés da Bahia. Salvador: EDUFBA.

. 2017. "O terreiro do Gantois: redes sociais e etnografia histórica no século XIX". Revista de História, São Paulo, n. 176:1-57.

COSSARD, Gisèle [Omindarewá]. 1970. Contribution à l'étude des candomblés au Brésil: le candomblé angola. Tese de Doutorado em Etnologia, École des Hautes Études en Sciences Sociales.

COSTA LIMA, Vivaldo da. 2003 [1977]. A Família de Santo nos Candomblés Jeje-Nagôs da Bahia: um estudo de relações intragrupais. Salvador: Corrupio.

ELBEIN, Juana. 2012 [1975]. Os nàgô e a morte: pàde, àsèsè e o culto égun na Bahia. Petrópolis: Vozes.

FLAKSMAN, Clara. 2014. Narrativas, relações e emaranhados: os enredos do candomblé no terreiro do Gantois, Salvador, Bahia. Tese de Doutorado em Antropologia Social, Universidade Federal do Rio de Janeiro.

FRAZIER, Franklin E. 1942. "The Negro Family in Bahia, Brazil". American Sociological Review, v. 7, n. 4:465-478.
GOLDMAN, Marcio. 1984. A possessão e a construção ritual da pessoa no candomblé. Dissertação de Mestrado em Antropologia Social, Universidade Federal do Rio de Janeiro. . 2003. "Os tambores dos mortos e os tambores dos vivos. Etnografia, antropologia e política em Ilhéus, Bahia". Revista de Antropologia, São Paulo, n. 46 (2):445-476.

. 2012. "O dom e a iniciação revisitados: o dado e o feito em religiões de matriz africana no Brasil". Mana: estudos de antropologia social, n. 18 (2):269-288. Rio de Janeiro: Contra Capa.

HALLOY, Arnaud. 2005. Dans l'intimité des orixás: corps, rituel et apprentissage religieux dans une famille-de-saint de Recife (Brésil). Tese de Doutorado em Ciências Sociais, Université Libre de Bruxelles.

. 2010. "'Chez nous, le sang règne!' L'apprentissage religieux dans le culte xangô de Recife". Terrain, 55:40-53.

HERSKOVITS, Melville. 1943. "The negro in Bahia, Brazil: a problem in method". American Sociological Review, 8:394-402.

SAHLINS, Marshall. 2011a. "What kinship is (part one)". Journal of the Royal Anthropological Institute, n.s., 17:2-29.

. 2011b. "What kinship is (part two)". Journal of the Royal Anthropological Institute, n.s., 17:227-249.

SANSONE, Livio. 2012. "Estados Unidos e Brasil no Gantois: O poder e a origem transnacional dos Estudos Afro-brasileiros". Revista Brasileira de Ciências Sociais, v. 27, n. 79:9-29.

SERRA, Ordep José Trindade. 1978. $\mathrm{Na}$ trilha das crianças: os erês num terreiro angola. Dissertação de Mestrado 
em Antropologia Social, Universidade de Brasília.

STRATHERN, Marilyn. 2000. ParentesCo, Direito e o Inesperado: Parentes são sempre uma surpresa. São Paulo: Editora Unesp.

VAN DE PORT, Mattijs. 2005. "Sacerdotes Midiáticos. O candomblé, discursos de celebridade e a legitimação da autoridade religiosa na esfera pública baiana". Religião e Sociedade, 25 (2):32-61. Rio de Janeiro: Instituto de Estudos da Religião.

VIVEIROS DE CASTRO, Eduardo B. 1996. "Os pronomes cosmológicos e o perspectivismo ameríndio". Mana, 2 (2):115-144. 


\section{"DE SANGUE" E "DE SANTO": O PARENTESCO NO CANDOMBLÉ}

\section{Resumo}

Este artigo investiga o parentesco, tanto "de santo" quanto "de sangue", a partir de uma etnografia do terreiro de candomblé Ilê Iyá Omi Axé Iyamassé (mais conhecido como Gantois), em Salvador, Bahia. O tema que abordo baseia-se numa reflexão sobre o parentesco no candomblé, mais especificamente sobre os modelos de transmissão dos orixás (e de outras entidades) entre os membros de uma mesma família e as possíveis conexões entre esses modelos e alguns dos princípios daqueles que se convencionou chamar "novos estudos do parentesco". O objetivo deste artigo é, portanto, analisar a questão do "parentesco de santo", entendido como a rede familiar que surge a partir da feitura do noviço em um terreiro de candomblé, e do "parentesco de sangue", a família consanguínea do iniciado, questionando assim a separação entre elas.

Palavras-chave Religiões afro-brasileiras, Candomblé, Parentesco, Relação, Enredo.

\section{'OF SAINT’ AND ‘OF BLOOD': KINSHIP IN CANDOMBLÉ}

\begin{abstract}
This article focuses on kinship relations established both through the "saints" (parentesco de santo) and through blood relations (parentesco de sangue), in the Candomblé temple of Ilê Iyá Omi Axé Iyamassé (better known as Gantois), situated in Salvador, Bahia, Brazil. I reflect on kinship relations in Afro-Brazilian religions, and more specifically on the models for the transmission of the orishas (and other entities) between family members, as well as the possible connections between those models and some of the principles of the so called "new kinship studies". This article therefore aims to analyse the matter of "saint kinship", seen as the family network that is created after a novice `s initiation into a Candomblé temple, and "blood kinship", the consanguineal family of the initiate, weaving differences and connections between one and the other.
\end{abstract}

Key words: Afro-Brazilian Religions, Candomblé, Kinship, Relation, Enredo. 
"DE SANTO" Y "DE SANGRE": EL PARENTESCO EN EL CANDOMBLÉ

\section{Resumen}

Este artículo investiga el parentesco, tanto "de santo" como "de sangre", desde una etnografía del terreiro Ilê Iyá Omi Axé Iyamassé (más conocido como Gantois) en Salvador, Bahía. El tema que abordo se basa en una reflexión sobre el parentesco en el candomblé, más específicamente sobre los modelos de transmisión de los orixás (y de otras entidades) entre los miembros de una misma familia y las posibles conexiones ente estos modelos y algunos de los principios de esos que se convino en llamar "nuevos estudios de parentesco". El objetivo del artículo es, por lo tanto, analizar el problema del "parentesco de santo', entendida como la red familiar que surge a partir de la hechura del novicio en un terreiro de candomblé, y del "parentesco de sangre", la familia consanguínea del iniciado, cuestionando así la separación ente ellas.

Palabras clave: Religiones afrobrasileñas, Candomblé, Parentesco, Relación, Enredo. 